\title{
Indirect Spectrophotometric Assay of Hydroxyurea with its Pharmaceutical Application as Capsules
}

\author{
Zainab W. Majid \\ Department of Chemistry \\ Wadala A. Bashir \\ College of Science \\ University of Mosul \\ E-mail:zainabwaleedm@yahoo.com \\ dwab52@yahoo.com
}

(Received 6/6/2012 ; Accepted 26/8/2012)

\begin{abstract}
The oxidation-reduction reaction between hydroxyurea and ferric ions has been utilised for spectrophotometric assay of hydroxyurea. The ferrous ions that are produced from the redox reaction were complexed with 2,2'-bipyridyl reagent to form a pink-red tris-chelate which has an absorption maxima at $522 \mathrm{~nm}$. Beers law agreed with the range of 5-150 $\mu \mathrm{g}$ of hydroxyurea per $20 \mathrm{ml}$, i.e., $0.25-7.5 \mathrm{ppm}$, with a corresponding average molar absorptivity of $1.65 \times 10^{4} 1 . \mathrm{mol}^{-1} . \mathrm{cm}^{-1}$, Sandell sensitivity index is $0.0044 \mu \mathrm{g} . \mathrm{cm}^{-2}$, limit of detection $0.01 \mu \mathrm{g} . \mathrm{ml}^{-1}$ and limit of quantitation of $0.03 \mu \mathrm{g} . \mathrm{ml}^{-1}$. The present method has been applied successfully to the determination of hydroxyurea in its pharmaceutical preparation as capsule.
\end{abstract}

Keywords: Hydroxyurea, 2,2'-bipyridyl, spectrophotometry.

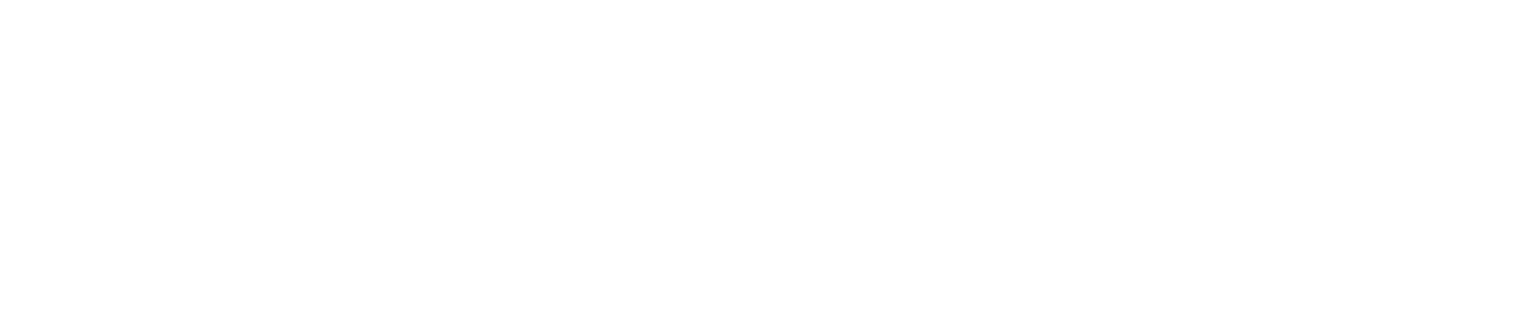

م في هذا البحث تقدير الهيدروكسي يوريا في المستحضر الصيدلاني عن طريق تقاعلات الاكسة والختزل وتعتمد الطريقة على لختزل اليون الحيد الثلاثي بـوسطة الهيدروكسي يوريا اله اليون الحيد يويدي الثنائي ڤم مفاعلة الحيد الثنائي مع الكلثف 2,'2 - ثنائي البيريدل لينتج معقداً كليتيَ مسقراً ذا لون لحمر وردي وأعطى أعلى لمتصاص عند طول موجي قدره 522 نانوميتر. وكانت حدود قانون بير الطريقة المقترحة في مدى الترلكيز 5 -150 مايكروغرله/20 مل أي (0.25-7.5) جزء لل مليون، لما قيمة معلمل

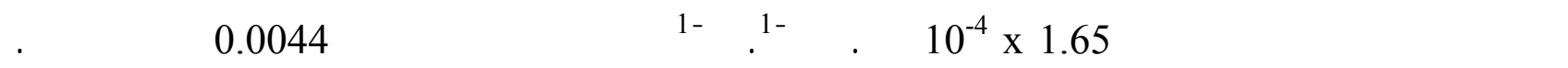

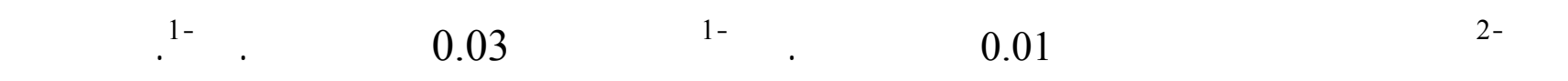
الطريقة بنجاح على المستحضر الصيدلاني للهيدروكسي يوريا علهشكل كبسول. 


\section{INTRODUCTION}

Hydroxyurea, $\mathrm{H}_{2} \mathrm{NCONHOH}$, is considered to be the derivative of hydroxylamine (Kovacic, 2011) or of the symmetrical urea molecule (Donehower, 1990). Since hydroxyurea blocks DNA synthesis by inhibiting ribonucleotide reductase (Koç et al., 2004), it therefore represents an effective treatment for sickle cell anemia and a number of cancers especially leukemias (Huang et al., 2002; Zhou et al., 2002 ; Rodriguez et al., 1998; Sommers et al., 2001; Kwon et al., 1991). Furthermore, it can serve as a source for the production of $\mathrm{NO}$ which plays an important role in the maintenance of normal blood pressure flow (Rupon et al., 2000). Such activity has led to the suggestion that hydroxyurea could be a possible HIV therapy (Frank et al., 2004). Hydroxyurea has also recently emerged as a new approved treatment for sickle cell disease (Lanzkron et al., 2008; Silva et al., 2011). The beneficial effects of hydroxyurea treatment to the sickle cell patient appear to result from an increase in the production of fetal hemoglobin (Platt, 2008), a genetically distinct hemoglobin that prevents the polymerisation of deoxy sickle cell hemoglobin (Steinberg et al., 2011).

To the best of our knowledge, the only visible spectrophotometric method for the determination of hydroxyurea is that based on its oxidation with excess iodine to form nitrite. The latter was allowed to diazotize sulfanilic acid to form the corresponding diazonium salt which is subsequently coupled with $\mathrm{N}-(1$-naphthyl)ethylenediamine to form a purple azo dye which has absorption maxima at $540 \mathrm{~nm}$. The method has been used to find the stability of hydroxyurea in oral solution (Heeney et al., 2004).

The present study is devoted to describe the development of a spectrophotometric method which is based on the color intensity of the pink tris-chelate of ferrous-bipyridyl system as a measure of original amount of hydroxyurea present in solution.

\section{EXPERIMENTAL}

\section{Apparatus}

Spectrophotometric measurements were performed on, using a Shimadzu UV-160 double-beam recording spectrophotometer with $1-\mathrm{cm}$ quartz cells.

$\mathrm{pH}$ readings were performed using HANNA $\mathrm{pH} 211$ Microprocessor $\mathrm{pH}$ meter with a combined glass electrode.

\section{Reagents}

All chemicals used were of the highest available purity.

Hydroxyurea stock solution $\left(\mathbf{1 0 0 0} \boldsymbol{\mu g} \cdot \mathrm{ml}^{-1}\right)$. This solution was prepared by dissolving $0.025 \mathrm{~g}$ of the compound (NDI, Iraq) in distilled water; the resulting solution was diluted to $25 \mathrm{ml}$.

Hydroxyurea working solution ( $\mathbf{5 0} \boldsymbol{\mu g}$. $\mathbf{~ m l}^{-1}$ ). This solution was prepared by diluting $5 \mathrm{ml}$ of the stock hydroxyurea solution to $100 \mathrm{ml}$ with distilled water. This solution is stable at least for 15 days.

Buffer solution (pH 2.7). This solution was prepared by mixing $50 \mathrm{ml}$ of $0.1 \mathrm{M}$ glycine solution with $12.1 \mathrm{ml}$ of $0.2 \mathrm{M} \mathrm{HCl}$ solution and diluting with distilled water to $100 \mathrm{ml}$ in a volumetric flask (Perrin and Dempsy, 1974).

Ferric ion solution $\left(1 \times \mathbf{x 1}^{-2} \mathrm{M}\right)$. This solution was prepared by dissolving $0.121 \mathrm{~g}$ of $\mathrm{Fe}\left(\mathrm{NH}_{4}\right)\left(\mathrm{SO}_{4}\right)_{2} \cdot 12 \mathrm{H}_{2} \mathrm{O}$ (Riedel-De Haen $\mathrm{AG}$ ) in distilled water that contains two drops of concentrated sulfuric acid and diluting the over all solution to $25 \mathrm{ml}$. 
2,2'-Bipyridyl reagent solution $\left(\mathbf{1} \mathbf{1} 10^{-2} \mathbf{M}\right)$. This solution was prepared by dissolving 0.156 $\mathrm{g}$ of the compound (ABCR GMbH and $\mathrm{Co.KG}$ ) in $4 \mathrm{ml}$ of ethanol then diluting the volume to $100-\mathrm{ml}$ with distilled water.

Foreign compound solutions $\left(\mathbf{1 0 0 0} \boldsymbol{\mu g} \cdot \mathbf{m l}^{-1}\right)$. These solutions were prepared either by dissolution in distilled water or in some ethanol and diluting to the mark with distilled water in a $100-\mathrm{ml}$ volumetric flask.

Capsule solution (500 $\mathbf{~ m g}$ hydroxyurea). This solution was prepared by dissolving an amount of capsule powder content $(0.05 \mathrm{~g})$ (Filaxis, Argentina) and diluting to volume (100 $\mathrm{ml})$ with distilled water.

\section{Recommended procedure and calibration graph}

To a number of 20 -ml volumetric flasks, 5 to $150 \mu \mathrm{g}$ of hydroxyurea, $2 \mathrm{ml}$ of ferric ion solution and $5 \mathrm{ml}$ of glycine buffer solution were added. The solution was left to stand for 5 minutes, then $3 \mathrm{ml}$ of the chromogenic reagent solution (2,2'-bipyridyl ), and finally distilled water was added to the mark. After 5 minutes, the absorbances against the corresponding reagent blank were measured at $522 \mathrm{~nm}$. The equation of the linear regression is $A=0.2176 C_{p p m}^{f}+0.0143\left(R^{2}=0.9992, n=12\right)$ [Fig. (1)]. Beer's law was agreed with the range of $5-150 \mu \mathrm{g}$ of hydroxyurea per $20 \mathrm{ml}$ (over this range will be negative deviation). The limit of detection and limit of quantitation are $0.01 \mu \mathrm{g} \mathrm{ml}^{-1}$ and $0.03 \mu \mathrm{g}$ $\mathrm{ml}^{-1}$, respectively (Valcarcel, 2000). The average molar absorptivity, with respect to hydroxyurea, at the wavelength of maximum absorption was $1.65 \times 10^{4} 1 . \mathrm{mol}^{-1} . \mathrm{cm}^{-1}$ and the sensitivity index was $0.0044 \mu \mathrm{g} . \mathrm{cm}^{-2}$.

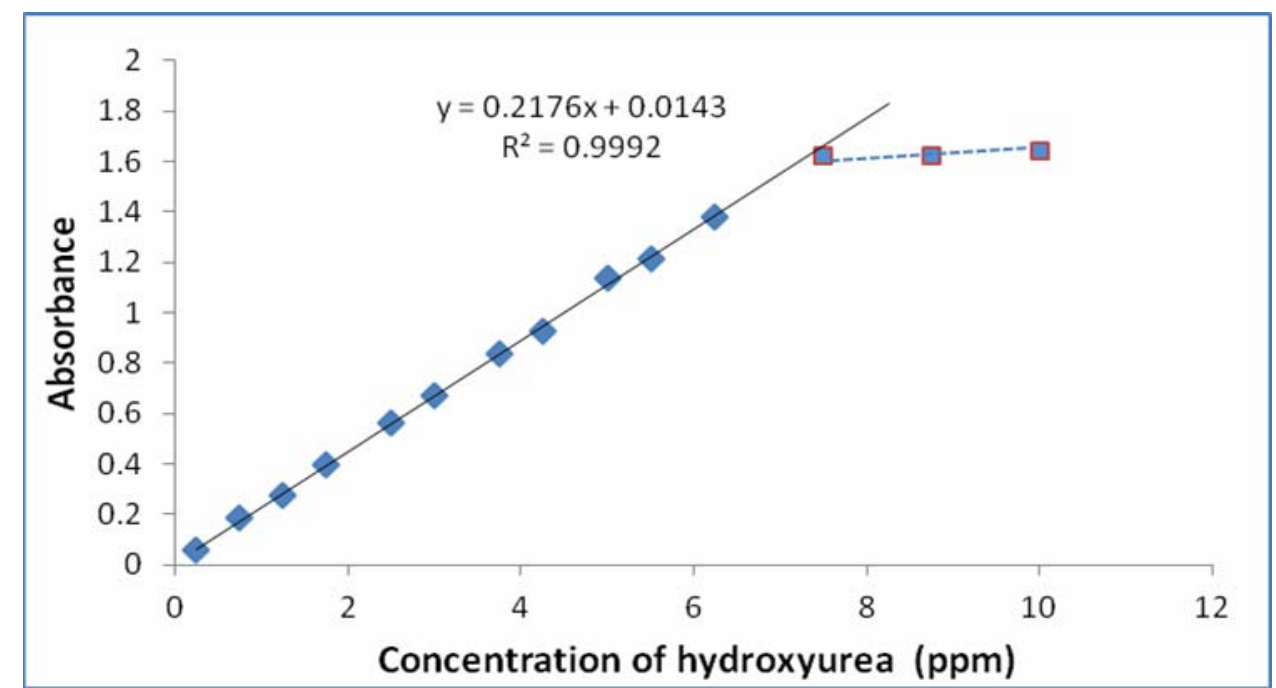

Fig. 1: Calibration graph for determination of hydroxyurea depending on the reaction between ferrous ion with 2,2 '-bipyridyl reagent. 


\section{RESULTS AND DISCUSSION}

\section{Principle of the method}

Hydroxyurea reduces ferric ions to the ferrous state which are subsequently complexed with 2,2'-bipyridyl (chromogenic reagent) to form the well-known tris-chelate of a red-pink color with absorption maxima at $522 \mathrm{~nm}$. This wavelength was maintained for absorbance measurements.

For the subsequent experiments, $50 \mu \mathrm{g}$ hydroxyurea was taken and final volumes were $20 \mathrm{ml}$.

\section{Optimisation of experimental conditions}

The various parameters affecting and related to the color intensity had been examined and optimized.

\section{Effect of pH}

The effect of $\mathrm{pH}$ on the color intensity was tested through the addition of (0.1-1.0) ml of $0.1 \mathrm{M} \mathrm{H}_{2} \mathrm{SO}_{4}$ to the reaction mixture, then measuring the absorbance of the final $(20 \mathrm{ml})$ solution against the blank solution, the results are shown in Table 1.

Table 1: Effect of pH on absorbance.

\begin{tabular}{|c|c|c|}
\hline ml of 0.1 $\mathbf{M ~ H}_{\mathbf{2}} \mathbf{S O}_{\mathbf{4}}$ & Absorbance & Final of pH \\
\hline 0 & 0.500 & 3.67 \\
\hline 0.1 & 0.546 & 2.93 \\
\hline 0.2 & 0.552 & 2.75 \\
\hline 0.3 & 0.556 & 2.67 \\
\hline 0.5 & 0.557 & 2.47 \\
\hline 0.7 & 0.568 & 2.31 \\
\hline 0.8 & 0.542 & 2.27 \\
\hline 0.9 & 0.493 & 2.22 \\
\hline 1.0 & 0.491 & 2.15 \\
\hline
\end{tabular}

The experimental data revealed that a $\mathrm{pH}$ of 2.93 to 2.27 gave a maximum intensity and a lower blank value. A series of buffers was prepared and tested for maximum color intensity. A glycine- $\mathrm{HCl}, \mathrm{KH}-$ phthalate, tartaric acid- $\mathrm{NaOH}$, and citric acid-NaOH buffers of $\mathrm{pH} 2.67$ were examined for maximum color intensity. Useful results were given by glycine- $\mathrm{HCl}$ and $\mathrm{KH}-\mathrm{phthalate}$. One-third of the intensity was given by tartaric acid- $\mathrm{NaOH}$ and citric acid- $\mathrm{NaOH}$ buffers due to their complexing ability of ferric ions which then resist reduction. A 1-7 ml of glycine- $\mathrm{HCl}$ buffer gave maximum color intensity and $5 \mathrm{ml}$ of the buffer was selected for the subsequent experiments.

\section{Effect of Oxidant}

The effect of various oxidant amounts $\left(1-5 \mathrm{ml}\right.$ of $\left.10^{-2} \mathrm{M}\right)$ of ferric ion oxidant on the intensity of the color produced was next investigated, the results are shown in Table 2 . 
Table 2: The effect of oxidant amount on absorbance.

\begin{tabular}{|c|c|c|c|c|c|}
\hline \multirow{2}{*}{$\begin{array}{c}\text { ml of oxidant } \\
(\mathbf{1 ~ x ~ 1 0 - 2} \mathbf{M})\end{array}$} & $\mathbf{5}$ & $\mathbf{2 5}$ & $\mathbf{5 0}$ & $\mathbf{1 0 0}$ & $\mathbf{R}^{\mathbf{2}}$ \\
\cline { 2 - 6 } & & & & & \\
\hline 1 & 0.060 & 0.285 & 0.537 & 0.965 & 0.9961 \\
\hline 2 & 0.102 & 0.281 & 0.552 & 1.106 & 0.9994 \\
\hline 3 & 0.061 & 0.286 & 0.564 & 1.128 & 1.00 \\
\hline 5 & 0.062 & 0.281 & 0.571 & 1.077 & 0.9991 \\
\hline
\end{tabular}

The results shown in Table 2 indicate that volume of $2 \mathrm{ml}$ of $10^{-2} \mathrm{M}$ solution gives a good determination coefficient and lower blank value (0.015) while replacing ferric ammonium sulphate by ferric chloride gave higher blank values. Also, ferric ammonium sulphate can be obtained in a more pure state than ferric chloride.

\section{Effect of reaction time}

The time needed to oxidize hydroxyurea quantitatively is 5 minutes. Also, it was found that extending oxidation time upto 30 minutes did not affect results.

\section{Effect of chromogenic reagent amount}

The effect of various amounts $\left(1-7 \mathrm{ml}\right.$ of $\left.10^{-2} \mathrm{M}\right)$ of 2,2'-bipyridyl reagent was tested and the results are shown in Table 3.

Table 3: Effect of reagent amount on absorbance.

\begin{tabular}{|c|c|c|c|c|c|c|}
\hline \multirow{2}{*}{$\begin{array}{c}\text { ml of reagent } \\
\left(\mathbf{1} \times \mathbf{~ 1 0}^{-2} \mathbf{M}\right) \\
\text { solution }\end{array}$} & \multicolumn{5}{|c|}{ Absorbance / $\mu$ g of hydroxyurea } \\
\cline { 2 - 7 } & $\mathbf{1}$ & $\mathbf{5}$ & $\mathbf{1 0}$ & $\mathbf{2 0}$ & $\mathbf{B l a n k}$ & $\mathbf{R}^{2}$ \\
\hline 1 & 0.057 & 0.197 & 0.302 & 0.487 & 0.009 & 0.9795 \\
\hline 3 & 0.072 & 0.291 & 0.571 & 1.111 & 0.018 & 0.9999 \\
\hline 5 & 0.070 & 0.285 & 0.548 & 1.099 & 0.026 & 0.9999 \\
\hline 7 & 0.070 & 0.292 & 0.531 & 1.077 & 0.028 & 0.9994 \\
\hline
\end{tabular}

From the above results, a $3 \mathrm{ml}$ of $10^{-2} \mathrm{M} 2,2^{\prime}$-bipyridyl chromogenic reagent solution gave maximum absorbance with a determination coefficient $\left(\mathrm{R}^{2}\right)=0.9999$ and the lower blank value (0.018).

\section{Effect of surfactansts}

The effect of various kinds of surfactants (cationic, CTAB; anionic, SDS ; and neutral, Triton X-100) on the color intensity of the chelate produced was investigated and the results are shown in Table 4. 
Table 4: The effect of surfactant.

\begin{tabular}{|c|c|c|c|c|c|}
\hline \multirow{2}{*}{$\begin{array}{c}\text { Surfactant } \\
\text { solution 3ml }\end{array}$} & \multicolumn{5}{|c|}{ Absorbance / order of addition } \\
\cline { 2 - 6 } & I & II & III & IV & V \\
\hline $\begin{array}{c}\text { CTAB } \\
1 \times 10^{-3} \mathrm{M}\end{array}$ & 0.565 & 0.556 & 0.569 & 0.560 & 0.555 \\
\hline $\begin{array}{c}\text { Triton X-100 } \\
1 \%\end{array}$ & 0.557 & 0.566 & 0.550 & 0.566 & 0.559 \\
\hline $\begin{array}{c}\text { SDS } \\
1 \times 10^{-3} \mathrm{M}\end{array}$ & \multicolumn{5}{|c|}{ Turbid solutions } \\
\hline
\end{tabular}

* $\mathrm{I}=$ Hydroxyurea $(\mathrm{Hu})+$ Buffer $(\mathrm{B})+$ Oxidant $(\mathrm{O})+$ Reagent $(\mathrm{R})$.

$\mathrm{II}=\mathrm{Hu}+$ Surfactant $(\mathrm{S})+\mathrm{B}+\mathrm{O}+5 \mathrm{~min}+\mathrm{R}$.

$\mathrm{III}=\mathrm{Hu}+\mathrm{B}+\mathrm{S}+\mathrm{O}+5 \mathrm{~min}+\mathrm{R}$.

$\mathrm{IV}=\mathrm{Hu}+\mathrm{B}+\mathrm{O}+5 \min +\mathrm{S}+\mathrm{R}$.

$\mathrm{V}=\mathrm{Hu}+\mathrm{B}+\mathrm{O}+5 \min +\mathrm{R}+\mathrm{S}$.

The results in Table 4 indicate that all types of surfactants do not have an effect on the intensity of absorbance, while SDS ( $5 \mathrm{ml}$ of $\left.10^{-3}\right)$ formed turbid reaction solution.

\section{Effect of order of reagents addition}

Table 5 shows the order of addition on absorbance.

Table 5: Order of addition of reagents.

\begin{tabular}{|l|l|c|c|}
\hline & \multicolumn{1}{|c|}{ Order } & $\begin{array}{c}\text { Abs. sample vs } \\
\text { blank }\end{array}$ & $\begin{array}{c}\text { Abs. blank vs } \\
\text { water }\end{array}$ \\
\hline I & $\mathrm{Hu}+\mathrm{Fe}+\mathrm{B}+\mathrm{R}$ & 0.575 & 0.016 \\
\hline II & $\mathrm{Hu}+\mathrm{B}+\mathrm{Fe}+\mathrm{R}$ & 0.594 & 0.016 \\
\hline III & $\mathrm{Hu}+\mathrm{Fe}+\mathrm{R}+\mathrm{B}$ & 0.579 & 0.008 \\
\hline
\end{tabular}

$\mathrm{HU}=$ Hydroxyurea , $\mathrm{B}=\mathrm{Buffer}, \mathrm{R}=$ Reagent.

From Table 5, the second order was the best choice because it gives the highest absorbance

\section{Effect of time}

The effect of time on the development and stability of coloured complex for different amounts of hydroxyurea is investigated under the optimum experimental conditions established, the results are shown in Table 6. 
Table 6: The effect of time on the absorbance of complex.

\begin{tabular}{|c|c|c|c|}
\hline \multirow{2}{*}{ Time (min.) } & \multicolumn{3}{|c|}{ Absorbance* / $\mu$ g Hydroxyurea } \\
\cline { 2 - 4 } & $\mathbf{2 5}$ & $\mathbf{5 0}$ & $\mathbf{7 0}$ \\
\hline 0 & 0.293 & 0.545 & 0.771 \\
\hline 5 & 0.292 & 0.550 & 0.796 \\
\hline 10 & 0.291 & 0.551 & 0.797 \\
\hline 15 & 0.292 & 0.551 & 0.795 \\
\hline 20 & 0.292 & 0.551 & 0.795 \\
\hline 25 & 0.291 & 0.551 & 0.794 \\
\hline 30 & 0.291 & 0.551 & 0.794 \\
\hline 35 & 0.291 & 0.551 & 0.795 \\
\hline 40 & 0.291 & 0.551 & 0.795 \\
\hline Abs/Blank & 0.018 & 0.020 & 0.019 \\
\hline
\end{tabular}

*The solution was left for five minutes after dilution to get the optimum stable absorbance readings.

From the above results, the complex was stable for at least 35 minutes only.

\section{Final absorption spectra}

Under the above established optimum conditions, the absorption spectra of standard treated according to the recommended conditions, versus the corresponding blank and distilled water and of blank versus distilled water are shown in Fig. (2). The absorption maxima was shown at $522 \mathrm{~nm}$ which was kept for subsequent absorbance measurements.

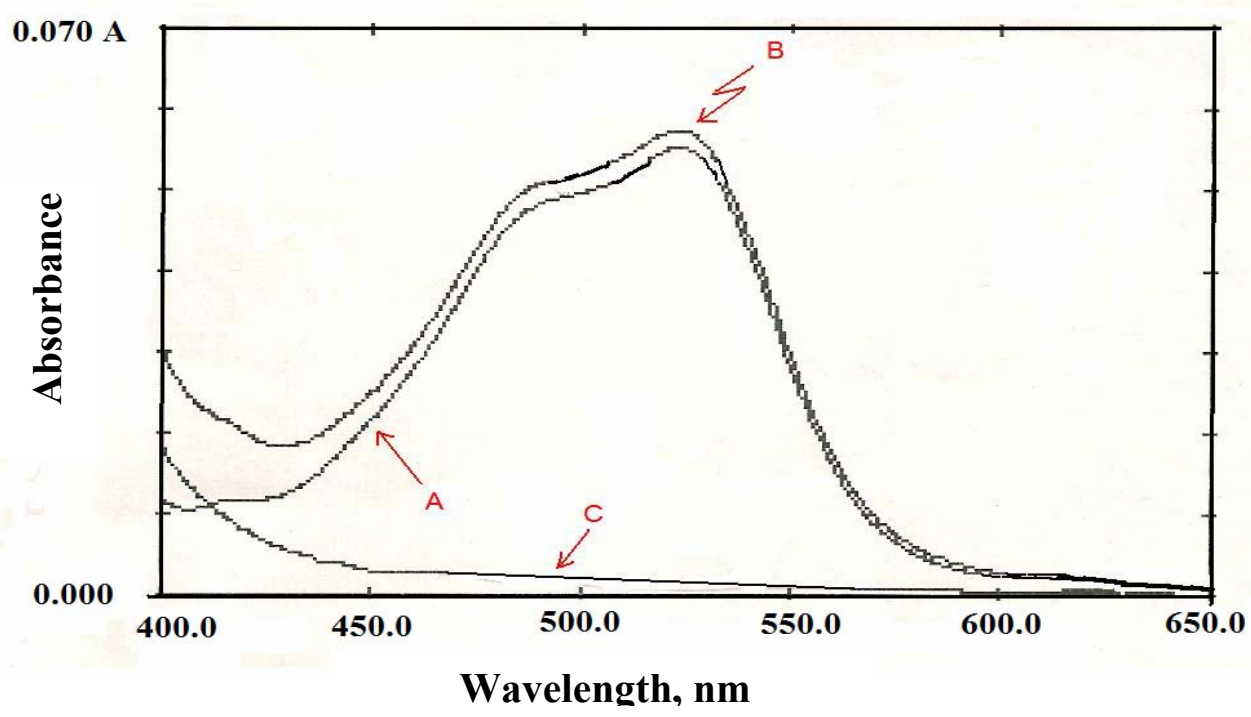

Fig. 2: Absorption spectra for final colored product versus the corresponding blank (A), absorbance spectrum versus distilled water (B) blank versus distilled water $(\mathbf{C})$. 


\section{Nature of the reaction}

Job's method of continuous variations (Fig. 3) was used to establish the stoichiometry (Delevie,1997) of the reaction between hydroxyrea and ferric ions. The obtained results indicated a 1:4 molar ratio of hydroxyurea to ferric ions so we propose the following reaction:

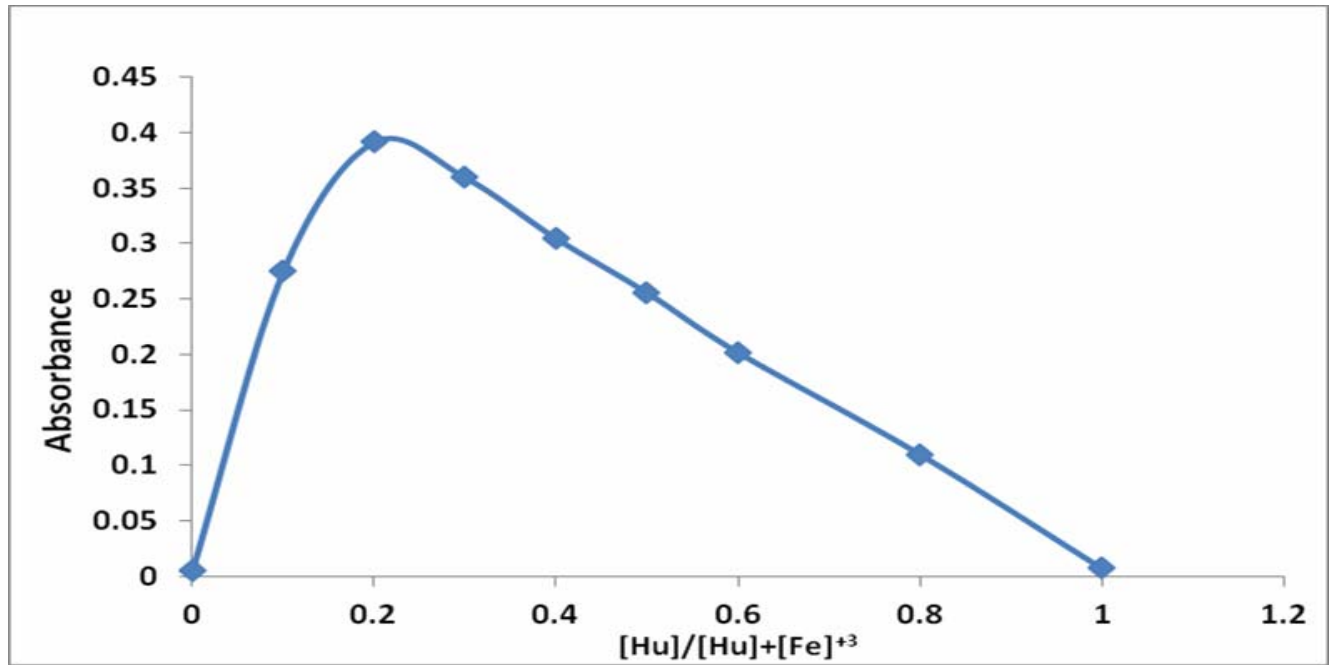

Fig. 3: Job's plot for hydroxyurea - Fe III .

\section{$\mathrm{H}_{2} \mathrm{NCONHOH}+4 \mathrm{Fe}^{+3} \longrightarrow \mathrm{N}_{2}+\mathrm{CO}_{2}+4 \mathrm{Fe}^{+2}+4 \mathrm{H}^{+}$}

When the mole-ratio method was applied a 1:5 to 1:6 molar ratio were obtained and we postulate the following reactions:

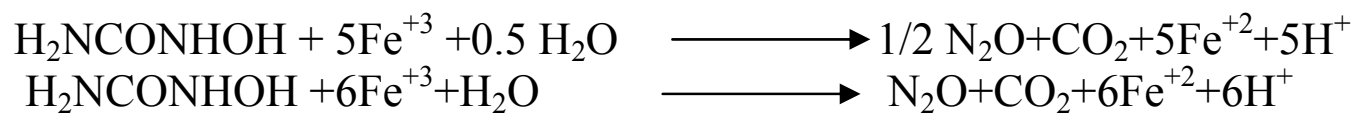

Whereas the molar absorptivity value of $17 \times 10^{3} 1 . \mathrm{mol}^{-1} \mathrm{~cm}^{-1}$ indicates a 1:2 molar ratio since the original value of $8.7 \times 10^{3} 1 . \mathrm{mol}^{-1} \cdot \mathrm{cm}^{-1}$, with respect to ferrous iron, so we suggest the following reaction:

\section{$\mathrm{H}_{2} \mathrm{NCONHOH}+2 \mathrm{Fe}^{+3 .} \longrightarrow \mathrm{H}_{2} \mathrm{NCONO}+2 \mathrm{Fe}^{+2}+2 \mathrm{H}^{+}$}

The iron in the ferrous state is complexed with 2,2-bipyridyl resulting in the formation of the characteristic pink-red tris-chelate which was stable and soluble in aqueous solution. On the other hand, ferric ions did not give this characteristic chelate in aqueous medium.

\section{Effect of organic solvents}

The reaction mixtures were diluted with some organic solvents instead of water in order to study their effects on the optical properties of the colored solution, the results are shown in Table 7. 
Table 7: The effect of organic solvents.

\begin{tabular}{|c|c|c|c|}
\hline Solvent & Abs & $\boldsymbol{\lambda}_{\max }(\mathbf{n m})$ & $\boldsymbol{\varepsilon}\left(\mathbf{l} . \mathbf{m o l}^{\mathbf{- 1}} \cdot \mathbf{c m}^{-\mathbf{1}}\right)$ \\
\hline n-propanol & 0.624 & 522 & $1.9 \times 10^{4}$ \\
\hline Ethanol & 0.638 & 522 & $1.9 \times 10^{4}$ \\
\hline Methanol & Turbid & ---- & ---- \\
\hline Acetone & 0.648 & 522 & $1.9 \times 10^{4}$ \\
\hline DMF & ---- & ---- & ---- \\
\hline Acetic acid & 0.726 & 522 & $2.2 \times 10^{4}$ \\
\hline Formic acid & 0.540 & 522 & $1.6 \times 10^{4}$ \\
\hline Water & 0.595 & 522 & $1.8 \times 10^{4}$ \\
\hline
\end{tabular}

It was found from Table 7 that acetic acid gave the highest molar absorptivity followed by acetone, ethanol and propanol and the least formic acid while when we use DMF gave a blank with a colour similar to that of the standard, which means that both ferric and ferrous ions will react with reagent together. A new fact that is yet discovered.

\section{Effect of interferences}

In order to assess the applicability of the developed method, the effect of various compounds at various levels on the determination of $50 \mu \mathrm{g}$ hydroxyurea was carried out. The results are given in Table 8 .

Table 8: Effect of foreign compounds on the determination of hydroxyurea.

\begin{tabular}{|c|c|c|c|c|}
\hline \multirow[t]{2}{*}{ Foreign compound } & \multicolumn{4}{|c|}{ 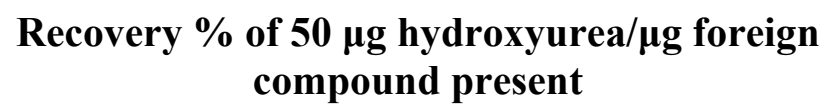 } \\
\hline & $25 \mu \mathrm{g}$ & $50 \mu \mathrm{g}$ & $100 \mu \mathrm{g}$ & $500 \mu \mathrm{g}$ \\
\hline Ascorbic acid & 122.3 & 134.4 & 175.7 & 435.2 \\
\hline Citric acid & 17.3 & 10.5 & 9.8 & 6.7 \\
\hline Calcium (as sulphate) & 98.3 & 98.3 & 101.2 & 99.6 \\
\hline Cadmium (as acetate) & 96.6 & 98.1 & 98.3 & 18.7 \\
\hline Copper (as sulphate) & 100.9 & 102.7 & 99.8 & 99.4 \\
\hline Glucose & 100.5 & 97.2 & 97.2 & 97.0 \\
\hline Gum acacia & 101.6 & 101.2 & 104.7 & 100.9 \\
\hline Hydrazine sulfate & 99.4 & 103.0 & 102.0 & 103.6 \\
\hline Hydroxylamine hydrochloride & 124.8 & 149.5 & 192.8 & 435.8 \\
\hline Lactose & 98.4 & 96.4 & 99.3 & 98.5 \\
\hline Lead (as nitrate) & 98.3 & 102.6 & 101.7 & 99.5 \\
\hline Magnesium stearate & 103.5 & turbid & turbid & turbid \\
\hline Paracetamol & 101.7 & 110.0 & 115.4 & 153.5 \\
\hline Povidone & 99.1 & 96.4 & 99.1 & 99.1 \\
\hline Sodium dihydrogen phosphate & 101.9 & 102.3 & 101.9 & 96.2 \\
\hline Sodium dodecyl sulfate & 95.5 & 96.4 & 97.5 & 98.5 \\
\hline Sorbitol & 99.1 & 102.6 & 99.5 & 99.1 \\
\hline Starch & 97.6 & 96.6 & 96.0 & 96.0 \\
\hline Urea & 99.0 & 97.2 & 97.4 & 97.8 \\
\hline Thiourea & 101.2 & 98.7 & 100.5 & 115.6 \\
\hline
\end{tabular}


The above results indicate that ascorbic acid, hydroxylamine, paracetamol and citric acid interfere to various extents. But fortunately these compounds are not present with hydroxyurea except citric acid which is present with hydroxyurea as additives. But we can reduce this interference by taking the smallest amount of sample possible.

\section{Application of the method}

The proposed method was successfully applied to the determination of hydroxyurea in capsule. The results which are shown in Table 9 indicate that good recoveries were obtained.

Table 9: Analytical applications.

\begin{tabular}{|c|c|c|}
\hline Pharmaceutical preparation & $\begin{array}{c}\boldsymbol{\mu g} \text { of Hydroxyurea } \\
\text { present / 20 ml }\end{array}$ & Recovery * \% \\
\hline \multirow{2}{*}{$\begin{array}{c}\text { Hydroxyurea capsule }(500 \mathrm{mg}) \\
\text { (Filaxis, Argentina) }\end{array}$} & 10 & 101.9 \\
\cline { 2 - 3 } & 50 & 101.2 \\
\cline { 2 - 3 } & 75 & 101.5 \\
\hline
\end{tabular}

*Average of five determinations.

The capsule, supplied (Filxas, Argentina), is labeled to contain $500 \mathrm{mg}$ per capsule was assayed by the present method and found to contain $(506.5 \pm 3.7) \mathrm{mg}$ and by the titrimetric British Pharmacopeia method (British Pharmacopeia, 1980) to contain (489 \pm 2.7$) \mathrm{mg}$. The tabulated $\mathrm{F}$ value (at $95 \%$ confidence interval) at 4 and 4 degrees of freedom is 6.3 which is larger than the calculated 1.2 value, indicating that there is no significant difference between the two methods.

\section{Comparison of the methods}

Table 10 shows the comparison between the present method and the standard method.

Table 10: Comparison of the methods

\begin{tabular}{|c|c|c|}
\hline Analytical parameter & Present method & Standard method* $^{*}$ \\
\hline $\mathrm{pH}$ & 2.6 & ----- \\
\hline Temperature & R.T & R.T \\
\hline$\lambda_{\text {max }} \mathrm{nm}$ & 522 & ----- \\
\hline Reagents used & 3 reagents & 3 reagents \\
\hline Principle reagent & 2,2 -bipyridyl & iodine \\
\hline Time of analysis & 10 min. & $20-25$ min. \\
\hline Determination range & $0.25-7.5 \mathrm{ppm}$ & ------ \\
\hline Molar absorpitivity,l.mol ${ }^{-1}, \mathrm{~cm}^{-1}$ & $1.65 \times 10^{4}$ & ------ \\
\hline reaction stoichiometry & $1: 4$ & ------ \\
\hline Recovery, $\%$ & 101.3 & 97.8 \\
\hline RSD, $\%$ & \pm 0.9 & \pm 0.7 \\
\hline Application & $\begin{array}{c}\text { Has been applied to the } \\
\text { assay of hydroxyurea in } \\
\text { capsule }\end{array}$ & $\begin{array}{c}\text { Has been applied to the assay } \\
\text { of hydroxyurea in tablets }\end{array}$ \\
\hline & & \\
\hline
\end{tabular}

*Britishpharmacopia, 1980 
The results indicate that the proposed method has a good sensitivity and has a wide application part in determination of the drug under investigation in its pharmaceutical preparation (capsule).

\section{CONCLUSION}

The proposed method for the spectrophotometric determination of hydroxyurea in capsule is simple, sensitive, rapid, accurate, and precise. The method is based on oxidationreduction reaction between hydroxyurea and ferric ion, then the subsequent reaction of ferrious ion with 2,2'-bipyridyl reagent in acidic medium to produce pink-red complex which is stable, water soluble and has a maximum absorption at $522 \mathrm{~nm}$. The relative standard deviation (RSD) was $\pm 0.9 \%$ depending on the concentration level. This means the proposed method has been applied successfully to the determination of the intended compound in capsule.

\section{REFERENCES}

British Pharmacopeia, Her Majesty's Stationary Office, London, (1980). 231 p.

Delevie, R. (1997). " Principle of Quantitative Chemical Analysis". Mcgraw-Hill, International Edition, Singapore, 498 p.

Donehower, R. C.; Chabner, B. A. ; Longo, D. L. (1990). "Hydroxyurea in Cancer Chemotherapy and Biotherapy". Eds., Lippincott Reven Co., Philadelphia, pp. 253-261.

Frank, I.; Bosch, R. J. ; Fiscus, S. (2004). Activity, safety, and immunological effects of hydroxyurea added to didanosine in antiretroviral-naive and experienced HIV type 1-infected subjects: a randomized, placebo-controlled trial. AIDS Res. Hum. Retroviruses, 20 (9), 916-26.

Heeney, M. M.; Whorton, M. R. ; Howard, T. A. ; Johnson, C. A. ; Ware, R.E. (2004). Chemical and functional analysis of hydroxyurea oral solutions. J. Pediatr. Hematol. Oncol., 26 , 179-184.

Huang, J. ; Hadimani, S.; Rupon, J. ; Ballas, S. ; KimShapiro, D. ; King, S. (2002). Iron nitrosyl hemoglobin formation from the reactions of hydroxyurea and hemoglobin, Biochemistry, 41, 2466-2474.

Koç, A.; Wheeler, L. J; Mathews, C.K ; Merrill, G.F. (2004). Hydroxyurea arrests DNA replication by a mechanism that preserves basal dNTP pools. J. Biol. Chem., 279 (1), 223-230.

Kovacic, P. (2011). Hydroxyurea (therapeutics and mechanism), metabolism, carbamoyl nitroso, nitroxyl radicals, cell signaling and clinical applications. Medical Hypothesis, 76, 24-31.

Kwon, N. S.; Stuehr, D. J. ; Nathan, C. F. (1991). Inhibition of tumor cell ribonucleotide reductase by macro- phage-derived nitric oxide. J. Exp. Med., 174, 1050-1058.

Lanzkron, S.; Strouse, J. J. ; Wilson, R. (2008). Systematic review: Hydroxyurea for the treatment of adults with sickle cell disease. Ann. Intern. Med. 148 (12), 939-955.

Perrin, D. D.; Dempsey, B. (1974). "Buffers for pH and Metal Ion Control". Chapman and Hall, London, 131p. 
Platt, O. S. (2008). Hydroxyurea for the treatment of sickle cell anemia. N. Engl. J. Med. $358(13), 1362-9$.

Rodriguez, G. I. ; Kuhn, J. G. ; Weiss, G. R. ; Hilsenbeck, S .G. ; Eckardt, J. R. ; Thurman, A. ; Rinaldi, D. A.; Hodges, S.; Von Hoff, D. D. ; Rowinsky, E. K. (1998). Abioavailability and pharmacokinetic study of oral and intravenous hydroxyurea. Blood, 91, 1533-1554.

Rupon, J. W. ; Domingo, S . R. ; Smith, S. V. ; Gummadi, B. K. ; Shields, H. ; Ballas, S. K.; King, S. B. ; Kim-Shapiro, D. B. (2000). The reactions of myoglobin, normal adult hemoglobin, sickle cell hemoglobin and human with hydroxyurea. Biophys. Chem. 84(1), 1-11.

Silva, D. H.; Junior, E. B.; Souza, L. de ; Torres, O. R.; Júnior, C. C.; Lobo, C.R. ; Almeida, E. A. (2011). Relationship between oxidative stress, glutathione Stransferase polymorphisms and hydroxyurea treatment in sickle cell anemia. Blood Cells, Molecules, and Diseases, 47(1), 23-28.

Sommers, E. M.; Huang, J.; Kim-Shapiro, D.B. ; King, S. B. (2002). Horseradish peroxidase catalyzed nitric oxide formation from hydroxyurea. J. Am. Chem. Soc., 124, 3473-3480.

Steinberg, M. H.; Zhi-Hong, L.; Barton, F. B. ; Terrin, M. L. ; Charache, S. ; Dover, G. J. (2011). Fetal hemoglobin in sickle cell anemia: determinants of response to hydroxyurea. Blood J. Hematol. Library. Org., 28, 1078-1088.

Valcarcel, M. (2000). " Principle of Analytical Chemistry". Springer-Verlag, Berlin Heidelberg, $207 \mathrm{p}$. and $69 \mathrm{p}$.

Zhou, B.; Mi, S. ; Mo, X. ; Shih, J. ; Tsai, J. ; Hsu, M. ; Yen, Y. (2002)."Time and sequence dependence of hydroxyurea in combination with gemcitabine in human KB cells", Anticancer Res, 22, pp. 1369-1377. 